\title{
The Food Safety Concern Level of Tourists That Experienced Ortaklar Cop Sis* Restaurants
}

\author{
Cevdet Avcikurt \\ Balikesir University, Faculty of Tourism, Balikesir, Turkey \\ E-mail: avcikurt@balikesir.edu.tr \\ Aysen Acun Koksalanlar (Corresponding author) \\ Uludag University, Iznik Vocational School, Bursa, Turkey \\ E-mail:aysenacun@uludag.edu.tr \\ Fusun Esenkal Cozeli \\ Balıkesir University, Institute of Social Sciences \\ E-mail:fusunesenkal@yahoo.com
}

\begin{abstract}
The aim of this study is define the food safety concern level of tourists that have experienced Ortaklar Cop Sis Restaurants. The questionnaire that prepared in this direction has been applied to 174 tourists that are used Ortaklar Cop Sis Restaurants between the dates of 23-26 September 2017. According to the research, three statements has been defined as the least upsetting conditions which are freeze storage, fat and cholesterol ratio and the restaurant not having the food safety certificate. On the other hand, the most concerned situations has been defined as the employee' inattentive behaviors about personal hygiene, mad cow and bird flu diseases, and the place that where the food is preparing is not being healthy. It appeared that the 39 participants $(\% 22,4)$ marked 1 point when they have been asked sufficiency of food safety level of the restaurants. While 49 participants $(\% 28,2)$ marked 1 point to sufficiency of food safety in Turkey, 30 participants $(\% 17,2)$ marked 5 points. It has been determined that participants learned the information about food safety mostly from radio and TV $(\% 63,2)$. It has been also determined that as the maximum number of the participants which are $84(\% 48,3)$ got knowledge about Iso9001 in terms of food safety information systems. Again, it has been determined that the women participants has more concern than the men participants.
\end{abstract}

Keywords: Ortaklar, Skewers, Food Safety, Concern Level

DOI: $10.7176 / \mathrm{JSTR} / 6-01-01$

*[Ortaklar Cop Sis: Ortaklar Çöp Şiş]

\section{Introduction}

The nutrition culture has been changed fastly from past to present. There have been important changes about many things like the diversity of food materials, production form, consumption location and presentation methods. During this time, the people' eating outside habit has increased and because of this, the number of businesses that provide food \& drink service has increased (Sevim and Görkem,2015). The food safety topic in the businesses that provide food \& drink service has become important for the customers. For the consumers, the food safety and quailty has a considerable impact on restaurant selection. From now on, consumers started making decisions about eating from the results of published food safety points. Again, for the consumers, it has becoming important that cleaning level of the restaurant, food and employee' hygiene, the presence of stink inside and outside of the restaurant, presence of flies, image of the food and freshness of the food (Uggioni and Salay,2012; Harris, Murphy, Dipetrio and Rivera, 2015). With the increase of importance of food safety topic, working on this topic has become important (Onurlubaş and Gürler, 2016). That's why, the research of concern level of food safety in Ortaklar Çöp Şiş Restaurants has been aimed.

1 I $\mathrm{P}$ a g e www.iiste.org 


\section{Literature Review \\ Food Safety}

Food safety has become increasingly important due to both public health and economical reasons for all the countries (İlbeği, 2004; Tunalığlu, Karaman, Çobanoğlu ve Ova, 2011). According to Regulation 27009 , food safety refers to the total of measures taken for the disposal of physical, chemical, biological and all kinds of damages in foods (Regulation of food safety and quality governance and its control, 2008). Physical risks; glass shards, plastic, piece of stone, soil, wood, metal (mercury, lead, dioxin, cadmium etc.), natural chemical in plants (for example glycoalkaloids in potatoes etc.), residues of veterinary and agricaltural medicines and food additives. It can be seen that biological risks are stems from bacterias within the scope of microbiological contamination that comes from viruses and parasites (Onurlubaş, 2015:34; Memiş and Üzel, 2008:49). Safety topic is one of the most important topics for many countries in terms of food (Alphonce, Alfnes ve Sharma, 2014).

Food safety has ben defined as "ensuring that all people are physically and economically able to access adequate, safe and nutritious food ad all times to meet their own nutritional requirements and to satisfy their food preferences for an effective and healthy life" at the World Food Summit in 1996 (Türkeş, 2014). Food safety is providing by complete application of hygenic conditions which do not harm the environment and the human health at all stages of the food chain (Giritoğlu and Kızılcık, 2016: 304; Buzbaş, 2010: 4). In order to ensure healthy and perfect food production, food safety defined as following the necessary rules and taking precautions during the production, processing preservation and the distribution of foods. Food safety, with the simplest definition, refers to "in line with it's purposes expresses the situation/process in which the food will not harm the consumer either when it is produced or consumed" (Koç, 2015; Unusan, 2009).

2009 The FDA Food Law has identified five risk factors that cause food-borne disease outbreaks, hospitalizations and deaths. These are; 1) the food that comes from unsafe source, 2) insufficient cooking, 3) dirty equipment, 4) false temprature, 5) lack of personal hygiene. Unsafe sources; it must come from approved vendor sources to ensure safety in terms of food integrity and quality of supply. The minimum internal temprature of the food that poorly cooked and the cooked food must be follow to be guaranteed because these foods contains harmful bacterias. The kitchenware that is not cleaned must be cleaned in every four hours to prevent the spread of pathogens and they must disinfect. Lastly, lack of personal hygen might be an improtant source to the spread of harmful bacterias and viruses to the foods or the equipment in the place that the food is produce (Harris, Murphy, Dipetrio and Rivers, 2015). Today, the food safety topic accepted as global health goal because of the food-borne diseases causing prominent health problem (Baser, Ture, Abubakirova, Şanlıer and Çil, 2016). Food safety has paramount importance for consumers, food industry and economy. The economical losts that caused by food-borne diseases shows that this situation can not be neglected no longer. It is known that the economical losts has reached one billion dollars in the last 20 years. This situation shows that the importance of food safety (Jevsnik, Hlebec and Raspor, 2008). Safe food improves economical growth at the area that apply and improve food safety (Fung, Mang and Menon, 2018).

When literature examined, Gözener, Büyükbaylı and Sayılı (2009), has determined that the 75 percent of participants know the concept of food safety, 76,92 percent of participants finds the food that they consume risky or too risky in terms of being healthy, and the 65,87 percent of participants said that they can paid more to safety food in their study. Furthermore, in their study, it is find that there is no relationship between knowing the concept of food safety and the participants' ages, gender, the places that participants come from and their residential criteria. Uzunöz, Büyükbay and Bal (2008) has determined that awareness of the safety of food products is increasing when the education level is increase at their study. There has been not determined any meaningful difference according to participants gender at Kocaman's (2014) study. Alpuğuz, Erkoç, Mutluer and Selvi (2009), in their study has been determined that schoolgirls read tag information significantly more than schoolboys when they buying packaged food. Göktolga and Karacier (2006), showed a result at their study that women consumers and the consumers that have high education level finds the foods too risky. It has determined that the 48,39 percent of participants do not know the food safety topic, 51,61 percent of participants has heard about this topic before. Additionally, it has determined that women participants are more likely to pay more to safe foods than the men participants.

It has appeared in the study of Gündüz and Aydoğan (2015) that the participants that hears food safety topic often do not show sufficient care about making food safety in terms of attitudes and behaviors.

2 I P a g e www.iiste.org 
Bekar (2013), according to result of his research, has determined that the elements that makes concerned the consumers mostly as antibiotic residues at the meat, milk, and the poultry, pesticide residual foods and the food additives. Özkaya, Şanlıer and Cömert (2008), has determined in their study that there is not any relationship between the participants' knowledge levef of food safety and their age range. Lee, Niode, Simenne and Bruhn (2012), at the consumer perception study on food safety in Asian and Mexican restaurants has determined that Mexican restaurants are seen to be more reliable than Asian restaurants and it has also determined that kitchen cleaning is the most important factor that affects food safety while toilet cleaning and cooking temprature follows that. Besides, the study showed that the food safety is effective in restaurant selection, women and elders are more careful about food safety than young men while eating outside, the consumers are getting information about food safety via internet and mouth to mouth, all the workers must be educated about food safety and the government should make an audit about food safety.

Onurlubaş and Gürler (2016) has conclude that women are more conscious than men about food safety. Additionally, they conclude that the possibility of being conscious about food safety is increasing when the age and education level are increase. At the Y1lmaz, Oraman and İnan (2009)'s study, it has been seen that the consumers that are lives urban and rural areas are mostly concerned about mad cow disease and bird flu. Furthermore, the least concerned issue that they have are freeze storage, irradiation method and the foods having additives and preservation substance. It has been determined at the study about food safety concern level that women are more willing to pay more than men for food safety (Alphonce, Alfnes and Sharma, 2014). Jevsnik, Hlebec ve Raspor, (2008), has been determined at their study that women are looking more to date of expiry than men. Liu and Lee (2018) has been determined the most important food safety aspects as employee' holding their nails clean, clean uniforms or employee' wearing protective clothes and workers wearing gloves while handling fast food at their study.

\section{Method}

The aim of this study is define the food safety concern level of tourists that are experienced Ortaklar Çöp Şiş restaurants. Questioannaire is used to gathering data for the intended purpose. The questionnaire has made to gather research data is consist of two chapter. The first chapter has questions to determine participants' demographic features while second chapter has questions to determine the participants' food safety knowledge level and their concern level about food safety. The universe of research made by tourists that are experienced Ortaklar Çöp Şiş restaurants. The questionnaire has been applied at September 2017 at Ortaklar restaurants. The survey has been answered by 200 tourists. 26 survey has been disregarded due to half of the questions did not answer by participants on those surveys and because of this 174 surveys has been evaluated.

The descriptive statistics for continious numerical variables has defined in this study which has been done to determine the concern level of food safety as mean, standart deviation and minimum and maximum values while categorical variables defined as number (n) and percentage (\%). Cronbach's alpha has been calculated for reliability analysis for "food safety concern level" questions (items). Parametric tests has been applied thanks to the participants that are involved to the surve were enough $(\mathrm{N}=174)$ and the reliability degree were high as 90,2 percent. The ANNOVA test and Independent T-test has been used to compare the questions according to demographic and other knowledge levels. Duncan test has been used to detect different categories on the comparisons that have meaningful difference as a result of ANNOVA test. Pearson's correlation coefficients has been used to determine knowledge level questions' relationship with the concern level of food safety. The calculation has been done by taking the avarage of points obtained from "'food safety concern levels". The statistical significance $(\alpha)$ has been assumed as 5 percent and SPSS (IBM SPSS for Windows, Ver.24) package program has been used for calculations.

The hypotheses that made after literature scan

$\mathrm{H}^{1}$ : There is a meaningful difference between gender variable and food safety concern level.

$\mathrm{H}^{2}$ : There is a meaningful difference between age variable and food safety concern level

$\mathrm{H}^{3}$ : There is a meaningful difference between education level and food safety concern level.

\section{Findigs}

\section{Findings According To Participants Demographic Features}

This chapter revealing the participants demographic features has been aimed. In this direction, the participants genders, ages and education levels has been asked. The findings about participants

3 I P a g e

www.iiste.org 
demographic features can be seen at table 1.

Table 1. Participants Ranges By Their Demographic Features ( $n=174)$

\begin{tabular}{llllll} 
Demographic variables & $\mathbf{n}$ & $\mathbf{\%}$ & Demographic variables & $\mathbf{n}$ & $\mathbf{\%}$ \\
\hline Age & & \multicolumn{6}{l}{ Gender } & 103 & 59.2 \\
\hline $18-28$ age & 50 & 28,7 & Man & 71 & 40,8 \\
\hline $29-38$ age & 59 & 33,9 & Woman & & \\
\hline $39-48$ age & 34 & 19,5 & Education & 25 & 14,4 \\
\hline $49-58$ & 19 & 10,9 & Primary Education & 13 & 7,5 \\
\hline 59 years old or older & 12 & 6,9 & Seondary School & 43 & 24,7 \\
\hline & & & Highschool & 77 & 44,3 \\
\hline & & & Bachelor's Degree & 16 & 9,2
\end{tabular}

As it can be seen at table 1,71 of participants $(\% 40,8)$ were women while 103 participants $(\% 59,2)$ were men in this research. When it comes to participants' age range, it can be seen that 59 of participants $(\% 33,9)$ are in the range between $29-38$ years old. In addition to this, 77 of participants $(\% 44,3)$ has Bachelor's degree.

Table 2: Ortaklar Questions ( $\mathrm{n}=174)$

\begin{tabular}{llllll} 
Being in Ortaklar Before & $\mathbf{n}$ & $\mathbf{\%}$ & The Days Stayed At Ortaklar & $\mathbf{N}$ & $\%$ \\
\hline Yes & 112 & 64,4 & Transit & 100 & 57,5 \\
\hline No & 62 & 35,6 & $1-2$ & 41 & 23,6 \\
\hline Holidays Plans & & & $3-4$ & 14 & 8,0 \\
\hline On My Own & 160 & 92,0 & $5-6$ & 14 & 8,0 \\
\hline Package Tour & 14 & 8,0 & 7 and more & 5 & 2,9
\end{tabular}

As it can be seen at table 2, the questions about Ortaklar and their holiday has been asked to participants. According to this, it has been determined that 112 of participants has been present at Ortaklar before, while 62 of participants has been not. The 92 percent of participants have answered that they do plan their holidays by their own when they have been asked how do they plan their holidays. When it has been asked that how long do they stay at Ortaklar, 57,5 percent of participants has answered as transit which means just eat at skewer restaurants. 
Table 3: Food Safety Questions ( $\mathrm{n}=174)$

\begin{tabular}{|c|c|c|c|c|c|c|}
\hline Food Safety Knowledge Level & $\mathbf{n}$ & $\%$ & & $\begin{array}{l}\text { Food Safety Adequacy } \\
\text { In Turkey }\end{array}$ & $\mathbf{N}$ & $\%$ \\
\hline 1 & 4 & 2 , & & 1 & 49 & 28,2 \\
\hline 2 & 1 & ,6 & & 2 & 23 & 13,2 \\
\hline 3 & 3 & 1 , & & 3 & 19 & 10,9 \\
\hline 4 & 10 & 5 , & & 4 & 15 & 8,6 \\
\hline 5 & 30 & & & 5 & 30 & 17,2 \\
\hline 6 & 21 & & & 6 & 11 & 6,3 \\
\hline 7 & 29 & & & 7 & 10 & 5,7 \\
\hline 8 & 34 & & & 8 & 6 & 3,4 \\
\hline 9 & 20 & & & 9 & 5 & 2,9 \\
\hline 10 & 22 & & & 10 & 6 & 3,4 \\
\hline How Careful Are You In Home & & & & Ortaklar Food Safety Suf & icienc & \\
\hline 1 & & 4 & 2,3 & 1 & 39 & 22,4 \\
\hline 2 & & 1 & ,6 & 2 & 10 & 5,7 \\
\hline 3 & & 5 & 2,9 & 3 & 6 & 3,4 \\
\hline 4 & & 5 & 2,9 & 4 & 8 & 4,6 \\
\hline 5 & & 26 & 14,9 & 5 & 22 & 12,6 \\
\hline 6 & & 17 & 9,8 & 6 & 12 & 6,9 \\
\hline 7 & & 21 & 12,1 & 7 & 21 & 12,1 \\
\hline 8 & & 27 & 15,5 & 8 & 23 & 13,2 \\
\hline 9 & & 24 & 13,8 & 9 & 13 & 7,5 \\
\hline 10 & & 44 & 25,3 & 10 & 20 & 11,5 \\
\hline Are You Interestin In Food Safe & Top & & & Which System Do You Kn & ow? & \\
\hline No & & 19 & 10,9 & НACCP & 18 & 10,3 \\
\hline Neutral & & 32 & 18,4 & ISO 9001 & 84 & 48,3 \\
\hline Yes & & 123 & 70,7 & ISO 22000 & 51 & 29,3 \\
\hline Total & & 174 & 100,0 & $\mathrm{BRC}$ & 16 & 9,2 \\
\hline Information Gathering Method & & & & IFS 14 & 14 & 8,0 \\
\hline Radyo tv & & 110 & 63,2 & All Of Them & 7 & 4,0 \\
\hline News Magazine & & 67 & 38,5 & None & 77 & 44,3 \\
\hline Internet & & 94 & 54,0 & & & \\
\hline Scientific Journal & & 23 & 13,2 & & & \\
\hline Friend & & 45 & 25,9 & & & \\
\hline Food Education & & 1 & ,6 & & & \\
\hline
\end{tabular}

Table 3 illustrate that 34 of participants $(\% 19,5)$ gave 8 points when food safety knowledge level has been asked while 30 of participants $(\% 17,2)$ gave 5 points. When it comes to the participants level of being careful about food safety at home, 44 of participants $(\% 25,3)$ has marked 10 points. It can be seen at the table 3 that 123 of participants $(\% 70,7)$ are interesting about food safety topic. 110 of participants $(\% 63,2)$ has answered radio and 94 of participants $(\% 54,0)$ has been answered the internet when they have been asked about the platform that they gather information about food safety. When it has been 
asked to participants that the food safety information systems, it can be seen that 84 of participants $(\% 44,3)$ has answered as none. 30 of participants $(\% 17,2)$ marked 5 points while 49 of participants $(\% 28,2)$ marked 1 point to the question about food safety adequacy in Turkey. 23 of participants $(\% 13,2)$ marked 8 points while 39 of participants $(\% 22,4)$ marked 1 point to the question about Ortaklar's food safety sufficiency.

Table 4. The Arithmetic Mean And Standart Deviation Related To Food Safety Statements

\begin{tabular}{lll} 
Item Statistics & Mean & Std. Dev. \\
\hline The place is not clean & 4,7011 &, 55067 \\
\hline Toilet is not clean & 4,6149 &, 74182 \\
\hline Kitchen stuff is not clean & 4,7529 &, 53961 \\
\hline Employees not clean & 4,7644 &, 51193 \\
\hline Kitchen personal is not clean & 4,8046 &, 47696 \\
\hline The place where the food is prepare & 4,7759 &, 53899 \\
\hline Food ingredients & 4,7011 &, 58131 \\
\hline Food additives & 4,4943 &, 74296 \\
\hline Genetically modified products & 4,6322 &, 63819 \\
\hline Frozen products & 3,5287 & 1,37558 \\
\hline Plant animal hormone & 4,6437 &, 62652 \\
\hline Allergenic & 4,5287 &, 78038 \\
\hline Fat cholesterol & 4,1149 & 1,16723 \\
\hline Mad cow & 4,7874 &, 53292 \\
\hline Foods \& Drinks & 4,7184 &, 65931 \\
\hline Restaurant food safety & 4,1322 & 1,13779 \\
\hline Cronbach's Alpha & Cronbach's Alpha & Total N \\
\hline ,902 &, 934 & \\
\hline
\end{tabular}

The standart deviation and mean of the answers that comes from tourists that are answered questions about food safety concern can be seen at table 4 . According to the table 4 , the freeze storage has been determined as the least concern of food safety of the tourists $(x=3,52)$. Fat and cholesterol ratio $(x=4,11)$ and the restaurant being not having the food safety certificate $(x=4,13)$ are the other statements that are determined as least concern of food safety. It has also determined that the most concern level of food safety of the tourists that experienced Ortaklar restaurants is in the statement of the employee' inattentive behaviors about personal hygiene $(\mathrm{x}=4,80)$. Mad cow and bird flu statement and the place that where the food is preparing is not being healthy statements are the other statements that have high concern level of food safety ( $x=4,78, x=4,77$ respectively)

The Cronbach's Alpha value of voer 0.75 indicates that the reliability of questionnaire is high. Thanks to reliability coefficient has found 90.2 percent, it has been conclude that questionnaires questions are reliable. The general descriptive statistics of the questions of food safety concerns which has been answered by a total of 174 individuals participated in the questionnaire were also shown in the table. According to this, while general concern levels of food safety is close to each other (between the range of $4,12-4,81)$, it has been answered as low concern level by participants to the question of frozen product $(3,52)$. 
Table 5. Comparison Of Food Safety Concern Levels By Gender

\begin{tabular}{lllllll} 
& $\mathrm{N}$ & Mean & Std. Dev. & Min. & Max. & $* \mathrm{p}$. \\
Men & 103 & 4,4507 &, 55890 & 1,63 & 5,00 & \multirow{2}{*}{, 006} \\
Women & 71 & 4,6663 &, 33346 & 3,56 & 5,00 & \\
Total & 174 & 4,5446 &, 48933 & 1,63 & 5,00 & \\
\multicolumn{5}{c}{ * Results of Independent T-test } \\
\cline { 2 - 5 }
\end{tabular}

Table 5 shows the comparison of the avarage of food safety concern levels by gender. The difference of the avarage of food safety concern levels according to participants' gender has been found meaningful $(p<0,05)$. According to this, it has been seen that women participants has more concern than men participants and thanks to this, $\mathrm{H}^{1}$ has been accepted.

Table 6. Comparsion Of Food Safety Concern Level By Age

\begin{tabular}{|c|c|c|c|c|c|c|}
\hline & $\mathbf{N}$ & Mean & $\begin{array}{l}\text { Std. } \\
\text { Dev. }\end{array}$ & Minimum & Maximum & *p. \\
\hline $18-28$ & 50 & 4,4412 &, 55714 & 41,63 & 5,00 & \multirow{5}{*}{,489 } \\
\hline $29-38$ & 59 & 4,5719 &, 47387 & 72,25 & 5,00 & \\
\hline $39-48$ & 34 & 4,5803 &, 44968 & 83,38 & 5,00 & \\
\hline $49-58$ & 19 & 4,5968 &, 46512 & 23,75 & 5,00 & \\
\hline $59-68$ & 12 & 4,6575 &, 40405 & 53,88 & 5,00 & \\
\hline Total & 174 & 4,5446 &, 48933 & 31,63 & 5,00 & *ANOVA test result \\
\hline
\end{tabular}

It has been shown that the comparison of food safety level by age at the table above. The difference of the avarage of food safety concern levels according to participants' age has not been found meaningful $(\mathrm{p}>0,05)$. Due to this, $\mathrm{H}^{2}$ has been rejected. It can be seen that age groups has not any impact on food safety concern levels. This is also shows that all of the individuals in the every range of age has close concern levels of food safety $(4,44-4,66)$ to each other. Even though the age variable is not important, the concern level is increasing when the age is increasing, however, this increase is not worthy of note.

Table 7. Comparison Of Food Safety Concern Level By Education

\begin{tabular}{|c|c|c|c|c|c|c|}
\hline & $\mathbf{N}$ & Mean & Std. Dev. & Minimum & Maximum & pp. \\
\hline Primary Education & 25 & 4,5212 & ,74041 & 1,63 & 5,00 & \\
\hline Secondary School & 13 & 4,2800 &, 81269 & 2,25 & 5,00 & \\
\hline Highschool & 43 & 4,6277 &, 40832 & 3,44 & 5,00 & ,253 \\
\hline Bachelor's Degree & 77 & 5377 &, 36827 & 3,81 & 5,00 & \\
\hline Post Graduate - Doctrin & 16 & 4,6063 & ,34119 & 3,94 & 5,00 & \\
\hline Total & 174 & 4,5446 & ,48933 & 1,63 & 5,00 & \\
\hline
\end{tabular}

It is seen that the comparison of food safety concern level by education at the table 7 . The difference of the avarage of food safety concern levels in terms of participants' education has not been found meaningful $(\mathrm{p}>0,05)$. In another saying, individuals education status has not have any significant impact on concern levels. That is why, $\mathrm{H}^{3}$ has been rejected. 
Table 8. Comparison Of Ortaklar Food Safety Adequacy In Terms Of Being In Ortaklar

N MeanStd. Dev. Mean DfStd. *p.

\begin{tabular}{l|llll}
\hline Yes1125,919 & 2,935 & 1,46 &, 489 \\
\hline No 62 & 4,451 & 3,56 & 1,46 &, 508
\end{tabular} 0,08

At the table above, the comparison of Ortaklar Food Safety adequacy in terms of being in Ortaklar has been shown. The difference of Ortaklar food safety adequacy in terms of being in Ortaklar has been found meaningful statistically $(p<0,05)$. According to this, it has been found that the participants that has been Ortaklar before found Ortaklar more adequate in terms of food safety than the participants that has been not Ortaklar before.

Table 9. Comparison Of Food Safety Concern Level By “'how do you plan your holiday” Question

N Mean Std. Dev. Minimum Maximum*p.

\begin{tabular}{lllll|}
\hline On my own & $1574,5731,48105$ & 1,63 & 5,00 & \multirow{2}{*}{019} \\
\hline Package tour17 & $4,2812,50101$ & 3,38 & 5,00 \\
\hline Total $1744,5446,48933$ & 1,63 & 5,00 \\
\hline \multicolumn{5}{c}{ *Independent T-tes result; }
\end{tabular}

It has been shown at the table 9 that the comparison of food safety concern level by "how do you plan you holiday" question. The difference of avarage of food safety concern levels according to the question of "how do you plan your holiday" question has been found meaningful statistically $(\mathrm{p}<0,05)$. Thanks to that data, it has been found that the participants that answered question as "by my own" has more concern than the participants that answered the question "package tour" $(4,28)$.

Table 10. Correlation Coefficients In Food Safety $(\mathrm{N}=174)$

\begin{tabular}{|c|c|c|c|c|c|c|}
\hline & $\begin{array}{l}\text { Turkey's } \\
\text { adequacy }\end{array}$ & $\begin{array}{c}\text { Food } \\
\text { Concern } \\
\text { Level }\end{array}$ & $\begin{array}{c}\text { Food Safety } \\
\text { Knowledge } \\
\text { Level }\end{array}$ & $\begin{array}{c}\text { Being } \\
\text { Careful } \\
\text { At Home }\end{array}$ & $\begin{array}{c}\text { Are You } \\
\text { Interesting }\end{array}$ & $\begin{array}{l}\text { Ortaklar } \\
\text { Adequacy }\end{array}$ \\
\hline $\begin{array}{l}\text { Turkey's } \\
\text { adequacy }\end{array}$ & 1 & . & & & & \\
\hline $\begin{array}{l}\text { Food Concern } \\
\text { Level }\end{array}$ & -024 & 1 & & & & \\
\hline $\begin{array}{l}\text { Food Safety } \\
\text { Knowledge Level }\end{array}$ &, $187^{*}$ & 143 & 1 & & & \\
\hline $\begin{array}{l}\text { Being Careful At } \\
\text { Home }\end{array}$ &, $276 * *$ &, $270 * *$ & $666 * *$ & 1 & & \\
\hline $\begin{array}{l}\text { Are You } \\
\text { Interesting }\end{array}$ & -080 &, $154 *$ &, $188 *$ & $.316^{* *}$ & 1 & \\
\hline Ortaklar &, $673 * *$ & 0,43 &, $295 * *$ & $416^{* *}$ & $153^{*}$ & 1 \\
\hline Adequacy & & & & & & \\
\hline
\end{tabular}

A positive and meaningful relationship is seen between the Ortaklar food safety adequacy and food safety adequacy in Turkey at table 10. In another saying, the participants that found Ortaklar's food safety adequacy enough, also found food safety adequacy in Turkey enough. Besides, there is a positive and meaningful relationship between being careful in terms of food safety at home and food safety concern 
level. According to this, it can be said that the participants that are being careful in terms of food safety at home has more food safety concern. Also, there is a positive relationship between being careful at home and food safety knowledge level. It can be said that participants being more careful about this topic when their knowledge level is increase.

\section{Conclusion and Suggestions}

This study defines the level of food safety knowledge and concerns of tourists who experienced Ortaklar şiş restaurants. The tourist that participated the questionnaire marked their level of food safety knowledge as 34 tourists $(19,5 \%) 8$ points, 30 tourists $(17,2 \%) 5$ points. When they have been questioned how much do you care at home to food safety, 44 of them replied $(25,3 \%) 10$ points. 123 participants $(70,7 \%)$ said that the questionnaire draw their attention. When they have been questioned how do they get the information about food safety, they replied $110(63,2)$ radio and TV, $94(54)$ internet. The information acquired from the study is consistent as Uzunöz and others work.

It has been defined that among the all food safety systems, Iso900 was the most known. Participants replied the food safety sufficiency in Turkey as, $49(28,2) 1$ point, $30(17,2) 5$ points. Whereas, for Ortaklar food safety sufficiency participants replied as, $39(22,4) 1$ point, $23(13,2) 8$ points.

Participants least concerned factors are, storing foods frozen, grease and cholesterol ratio, the restaurant not having food safety certificate. The most concerned factors are: kitchen staff's personal hygine, mad cow and bird flu, the kitchens cleanliness. The outcome of the study is consistent with the studies of Yllmaz, Oraman, İnan (2009). The study indicated that women are more concerned than men. The result is consistant with Alpoğuz and others, 2009; Bal Göktolga, Karkacier, 2006; onurlubaş, Gürler, 2006; Lee and others, 2012, Jevsnik and others', 2008 work. Additionally, it has been specified that range of age has no effects on food safety concern level. This result is consistant with Uzunöz and others (2008), Özkaya, Şanlıer, Cömert (2008). Another outcome of the study is, the consumers that plan his or her trip for themselves are more tend to concern about food safety level. Tourists that plans their vacation individually are more likely to concern about restaurants since they know a little about the place. Otherwise, the participants that mind about food safety level are more likely to concern about it. The participants who has knowledge about food safety are more concerned about food safety while at home or when they are shopping. Furthermore, the participant that had been in Ortaklar more then once think the restaurant is adequate.

The result of the study shows that majority of the participants only know Iso9001. In this regard, consumers can be trained and public spots can be organized. The participants concern the most about hygiene and health. Personnel working in the restaurants can be trained and raise the employees awareness. Thus, consumers' hygiene and health concern levels can be reduced. Another topic that participants mentioned are bird flu and mad cow diseases. If the restarurant keep consumers informed about raw material supply processes, the consumers concerns may drop.

This study's theoretical frame is limited to sources collected, empirical application study is limited to Ortaklar restaurant customers that willing to participate the study. In further studies, sampling group can be expand and reach more tourist and restaurants in Ortaklar area.

\section{References}

270009 Gıda Güvenliği ve Kalitesinin Denetimi ve Kontrolüne Dair Yönetmelik, 2008.

Alphonce, R.,Alfnes, F., Sharma, A. (2014). Consumer vs. citizen willingness to pay for restaurant food safety. Food Policy, 49, 160-166.

Alpuğuz, G., Erkoç, F., Mutluer, B., Selvi, M. (2009). Gençlerin (14-24 yaş) gıda hijyeni ve ambalajlı gıdaların tüketimi konusundaki bilgi ve davranışlarının incelenmesi. Türk Hijyen ve Deneysel Biyoloji Dergisi, 66 (3), 107-115.

Bal, H. S. G.,Göktolga, Z. G., Karkacıer, O. (2006). Gıda güvenliği konusunda tüketici bilincinin incelenmesi (Tokat ili örneği). Tarım Ekonomisi Dergisi, 12 (1), 9-18.

Baser, F.,Ture, H., Abubakirova, A., Sanlier, N., Cil, B. (2016). Structural modeling of the relationship among food safety knowledge, attitude and behavior of hotel staff in Turkey. Food Control. 1-7.

9 | $\mathrm{P}$ a g e

www.iiste.org 
Bekar, A. (2013). Tüketicilerin gıda güvenliğine yönelik tutumları. Yüzüncü Yll Üniversitesi Tarım Bilimleri Dergisi, 23(2), 90-101.

Buzbaş, N. (2010). Türkiye ve AB'de gıda güvenliği: Ortaklığın sinerjisi. 28. Türkiye-AB Karma İstişare Komitesi Toplantısı. Edinburg.

Fung, F.,Wang, S. H., Meenon, S. (2018). Food safety in the 21st century. Biomedical journal, $41(2) 88-95$.

Giritlioğlu, İ., Kızılcık, O. (2016). Turizme hizmet sunan pastane işletmelerinde çalışan dondurma üretim personelinin hijyen ve gıda güvenliğine ilişkin bilgi ve uygulama düzeyi üzerine bir araştırma. Mehmet Akif Ersoy Üniversitesi Sosyal Bilimler Enstitüsü Dergisi, 8 (15), 301-319.

Gözener, B., Büyükbay, E. O., Sayılı, M. (2009). Gıda güvenliği konusunda öğrencilerin bilgi düzeylerinin incelenmesi. Gaziosmanpaşa Üniversitesi Ziraat Fakültesi Dergisi, 26(2), 4553.

Gündüz, O., Aydoğan, C. (2015). Önlisans öğrencilerinin gıda güvenliği bilinç düzeyleri üzerine bir araştırma. Akademik Yaklaşımlar Dergisi, 6(1), 34-44.

Harris, K. J., Murphy, K. S., Di Pietro, R. B., Rivera, G. L. (2015). Food safety inspections results: A comparison of ethnic-operated restaurantstonon-ethnic-operated restaurants. International Journal of Hospitality Management, 46, 190-199.

Ilbeği, I. (2004). Gıda güvenliği ve tüketicinin korunması. Glda Mühendisliği Dergisi, 18, 1316.

Jevsnik, M.,Hlebec, V., Raspor, P. (2008). Consumers' awareness of food safety from shopping to eating. Food control, 19(8), 737-745.

Kocaman, E. M. (2015). Yiyecek ve içecek işletmeciliği eğitiminin öğrencilerin gida güvenliği bilgi düzeyine etkisi. Kastamonu Ĕgitim Dergisi, 23(1), 269-280.

Koç, E. (2015). Gıda güvenliği ve kamu sağlığının korunması, TAAD, 6(22) (Temmuz), 395426.

Lee, L. E.,Niode, O., Simonne, A. H., Bruhn, C. M. (2012). Consumer perceptions on food safety in Asian and Mexican restaurants. Food Control, 26(2), 531-538.

Liu, P., Lee, Y. M. (2018). An investigation of consumers' perception of food safety in the restaurants. International Journal of Hospitality Management, 73, 29-35.

Memiş, E.,Üzel, R. (2008). Turizm sektöründe gıda güvenliği. Standart, Temmuz, 47-53.

Onurlubaş, E. (2015). Tüketicilerin gıda güvenliği konusunda bilinç düzeylerinin ölçülmesi: Tokat ili örneği. Yayınlanmamış Doktora Tezi, Gazi Osman Paşa Üniversitesi, Ankara.

Onurlubaş, E.,Gürler, A. Z. (2016). Gıda güvenliği konusunda tüketicilerin bilinç düzeyini etkileyen faktörler. Gaziosmanpaşa Üniversitesi Ziraat Fakültesi Dergisi, 33(1), 132-141.

Özkaya, D, F.,Şanlıer, N., Cömert, M. (2008). Otellerde yiyecek içecek hizmetlerinde çalışan personelin gıda güvenliği bilgi düzeyi. Türkiye 10. Gıda Kongresi; 21-23 Mayıs 2008, Erzurum. 
Sevim, B., Görkem, O. (2015). Gastronomi ve aşçılık programlarında gıda güvenliği donanım altyapısının değerlendirilmesi. Uluslararası Alanya İşletme Fakültesi Dergisi, 7(1), 59-67.

Tunalıoğlu, R., Karaman, A. D., Çobanoğlu, F., Ova, G. (2011). Sofralık zeytin işletmelerinde gıda güvenliği yönetim sistemlerinin (ggys) uygulanma durumu ve işletme yöneticilerinin bilgi düzeylerinin belirlenmesi. Adnan Menderes Üniversitesi Ziraat Fakültesi Dergisi, 8(2), $7-13$.

Türkeş, M. (2014). İklim değişikliğinin tarımsal gıda güvenliğine etkileri. Türk Tarım - Gıda Bilim ve Teknoloji Dergisi, 2(2): 71-85.

Uggioni, P. L.,Salay, E. (2012). Reliability and validity of a scale to measure consumer attitudes regarding the private food safety certification of restaurants. Appetite, 58(2), 470-477.

Unusan, N. (2007). Consumer food safety knowledge and practices in the home in Turkey. Food Control, 18(1), 45-51.

Uzunöz, M., Büyükbay, E. O., \& Bal, H. S. G. (2008). Kırsal kadınların gıda güvenliği konusunda bilinç düzeyleri (Tokat İli Örneği). Uludağ Üniversitesi Ziraat Fakültesi Dergisi, 22(2), 35-46.

Yılmaz, E.,Oraman, Y., İnan İ. H. (2009). Gıda ürünlerine ilişkin tüketici davranışı dinamiklerinin belirlenmesi: Trakya örneği. JOTAF/Tekirdağ Ziraat Fakültesi Dergisi, 6(1), $01-10$. 